International Journal of Advances in Biology (IJAB) Vol 2. No .3, August 2015

\title{
RESIDUAL ESTIMATION OF ISOPROTURON, ATRAZINE AND GRAIN PROTECTANTS IN STORED WHEAT GRAINS
}

\author{
M. Tariq*, S. Bushra ${ }^{1}$, Mansoor-ul-Hassan ${ }^{2}$, U. Maqbool $^{3}$, M. R. Asi ${ }^{4}$, A. \\ Gulzar $^{5}$ and M. F. Iqbal ${ }^{6}$. \\ *Assistant Professor, Department of Entomology, Pir Mehr Ali Shah, Arid Agriculture \\ University, Rawalpindi, Pakistan. \\ ${ }^{1} \mathrm{Ph} . \mathrm{D}$ Scholar, Department of Entomology, Pir Mehr Ali Shah, Arid Agriculture \\ University, Rawalpindi, Pakistan. \\ ${ }^{2}$ Associate Professor, Department of Agri. Entomology, University of Agriculture, \\ Faisalabad, Pakistan. \\ ${ }^{3}$ Principal Scientist, Aflatoxin Laboratory, NIAB, Faisalabad, Pakistan. \\ ${ }^{4}$ Senior Scientist, Pesticide Residue Laboratory, NIAB. \\ ${ }^{5}$ Assistant Professor, Department of Entomology, Pir Mehr Ali Shah, Arid Agriculture \\ University, Rawalpindi, Pakistan. \\ ${ }^{6}$ Assistant Research Officer, Adaptive Research Farm, Gujranwala, Pakistan.
}

\begin{abstract}
This study was carried out to see the occurrence and level of pesticide residues in stored wheat grain samples. Wheat grains were collected from different godowns located in Faisalabad district. Weedicide residues in wheat grains were analyzed by using thin plate liquid chromatography and validated high performance liquid chromatography. On the basis of extent of inhibition of the Hill reaction, it was found that the level of atrazine was $\left(0-0.028 \mathrm{ngkg}^{-1}\right)$ and the level of isopproturon was $\left(0-0.024 \mathrm{ngkg}^{-1}\right)$ in test samples. The calculated values were below the Maximum Residue Limit (MEL) i.e. $100 \mathrm{ngkg}^{-1}$ for atrazine and $2200 \mathrm{ngkg}^{-1}$ for isoproturon. It was found that presence of herbicide residues in stored wheat was negligible. Further, on wheat grain samples placed in jars and treated with deltamethrin and cypermethrin $@ 0.4$ and $0.8 \%$ concentration. The persistency data was calculated after 1 hour, 7, 15 and 30 days of treatment. The grain protectants were continuously degraded with the passage of time and after the 30 days the amount of residues of the grain protectants was found to be very small. It was concluded that the use of the grain protectants in the powder form in combination with other botanicals on stored wheat samples is feasible to reduce the insect pest in stored grains.
\end{abstract}

\section{INTRODUCTION}

Wheat, Triticum aestivum L. is most important cereal crop worldwide. It is known as the 'King of cereals'. About 681 MT of wheat is produced annually on 225 mha of total cultivated world production area (Rehman et al. 2013). Pakistan is $8^{\text {th }}$ largest country in wheat grain production. In Pakistan, it contributes $2.6 \%$ to GDP. Wheat grain production in current year is 24000 MT in Pakistan (Indexmundi, 2013). Various pesticides are widely being used during cropping period and grain storage to protect food commodity from pest attack. The production loss is about $40 \%$ without the use of pesticides (Riazuddin et al. 2011a). About 9\% of grain losses are due to stored product insects in developed countries and more than $20 \%$ in the under developed countries

DOI : $10.5121 /$ ijab.2015.2302 
International Journal of Advances in Biology (IJAB) Vol 2. No .3, August 2015

(Phillips and Throne 2010).

Insecticides, herbicides and fungicide application play a vital role in modern crop production technology (Riazuddin et al. 2011b). Several grain protectants are used alone and in a combination to control stored grain pests. The grain protectants include fenitrothion, malathion, pirimifos methyl, cypermethrin, deltamethrin and diatomaceous earth (Daglish, 1998). No doubt, pesticide application can control every kind of pest but these chemicals leave certain residues in commodities (Cesnik et al., 2007; Anwar et al., 2011). The overuse of insecticides left residues in cereals grains. Presence of pesticide residues in food products has hazards to non-target mammals and our environment (Chitanat et al., 2008). When these residues enter in the food chain, they are results public health risks (Khan et al., 2007). To avoid potential hazards due to insecticide application, developed countries have established Maximum residue Levels (MRL's) of insecticides (Pang et al. 2009). However, pesticides should be selected on the basis of minimum mammalian toxicity to minimize the residual toxicity level in agricultural commodities (Riazuddin et al. 2011b).

Weeds reduce the grain yield (Najafi and Tollenaar 2005). Weeds should be managed via integrated weed management systems to avoid grain yield loss (Mohler 2001). Use of fertilizer can reduce weed growth (O'Donovan et al. 2001). Herbicides have been used for weed control for more than 30 years (Zand et al., 2007). Nowadays, herbicides play an integral part in weed management (Rao 2000; Baghestani et al. 2005). But most of herbicides used cannot significantly control the weeds (Najafi and Ghadiri 2012).

Atrazine is a triazine herbicide with chemical formula (6-chloro- $N$-ethyl- $N N^{\prime}$-(1-methylethyl)1,3,5-triazine-2,4-diamine). It was introduced in 1950 (Steinberg et al. 1995). It is topmost used weedicide which is applied in 70000-90000 tons per year (Steinberg et al. 1995). The European Union has banned atrazine in 2004 (European Commission 2004). About 1\% of atrazine is mixed in underground water per year (Freeman et al. 2011) and it can move upto 1,000 km from the source in our ecosystem (Mast et al. 2007; Thurman and Cromwell 2000). It is endocrine disruptor in mammals (Hayes et al. 2010) birds and rodents (Matsushita 2006; Friedman 2002).

Isoproturon is a selective herbicide with chemical formula (3-(4-isopropylphenyl)-1,1dimethylurea). It is used to control broad-leaved weeds (Mamy et al. 2011; Sørensen et al. 2003). The degradation of isoproturon in soil is biological (Sørensen et al. 2003). Its laboratory half-life is (6-223) days (Alletto et al. 2006).

Cypermethrin is a synthetic type II pyrethroid with chemical formula [(R,S)-alpha-cyano-3phenoxybenzyl (IRS)-cis, trans-3-(2,2-dichlorovinyl)-2,2-dimethyl cyclopropane carboxylate]. It is a derivative of Chrysanthemum indicum (Solati et al. 2010). Cypermethrin is a fourthgeneration insecticide (Elbetieha et al. 2001). It can cause severe adverse effects in invertebrates and vertebrates as well (Gowlan et al. 2002; Das and Mukherjee 2003). It is a neurotoxicant (Wolansky and Harril 2008).

In order to determine the degree of pesticide residues in food commodity, a number of monitoring programs are implemented nowadays. To determine pesticide residues in stored cereal grains, use of gas chromatography technique (GC/MS) along with (ECD, FID) is becoming popular (Uddin et al. 2011). Guo-Fang et al. (2006) reported that about 405 of pesticides residues can be 
International Journal of Advances in Biology (IJAB) Vol 2. No .3, August 2015

measured by using GC/MS and LC-MSMS technique in agricultural commodities. Aldanamadrid et al. (2008) analyzed 135 grain samples from different storage sites. It was found that

residues of Malathion, chlorpyrifos, deltamethrin, cypermethrin, 4,4-DDE, 4,4-DDD and 4,4DDT were present in significant amounts in tested grains.

In this study, we have investigated the presence and magnitude of pesticide residues in stored wheat grain samples collected from different godowns. The weedicides and grain protectants residues present in stored wheat will be determined by thin plate liquid chromatography and validated high performance liquid chromatography.

\section{MATERIALS AND METHODS}

\subsection{Wheat Sampling}

Wheat grain samples of $1.00 \mathrm{Kg}$ were collected from various godowns of food department located in Faisalabad district. All collected samples were stored at $4^{\circ} \mathrm{C}$ for residual analysis of atrazine and isoproturon.

\subsection{Weedicide Residual Analysis}

Methods for the determination of weedicide residues are continually being revised and improved with new and conventional techniques. Following steps are involved in determination of weedicide residues.

\subsubsection{Extraction of Herbicide Residues from wheat Samples}

Many solvents like n-hexane, petroleum ether, methylene chloride and acetone or ethyl acetate have been used as extraction solvents in the past (Cairns et al., 1993). In the present study, 100g sub-sample was taken from each sample. These samples were put in the deep freezer to avoid herbicide degradation. Half of the sub-sample $(50 \mathrm{~g})$ was taken to blend for $2-3$ minutes in $20 \mathrm{ml}$ of distilled water. The mixture was left to stay for $15 \mathrm{~min}$ so that wheat grains become well soaked. Thereafter, $20 \mathrm{~g}$ anhydrous Sodium sulphate was added to it so that it can absorb the remaining water, and $50 \mathrm{ml}$ of ethyl acetate was added to it and blended for $3 \mathrm{~min}$. The solvent layer was filtered with whatman filter paper (42). Then this extract was transferred in to round bottom flask. Further, the sample volume was reduced up to $1 \mathrm{ml}$ using rotary evaporator. The final volume was evaporated in water bath $(40 \mathrm{oC})$ with nitrogen stream to dryness and the residues were re-dissolved in $0.5 \mathrm{ml}$ (cyclohexane: ethyl acetate; 1:1 ratio) and Gel Permeation Chromatography technique was performed for cleaning up. Then the sample was analyzed with TLC technique by using photosynthetic inhibition method (Hill reaction).

\subsubsection{Gel Permeation Chromatography}


International Journal of Advances in Biology (IJAB) Vol 2. No .3, August 2015

Gel permeation chromatography has been widely used for the cleanup of various sample matrices, with several gel solvent systems. One of the most applicable gel is Bio Bead SX-3, its applicability has been tested for a large number of pesticide residues (Anderson and Ohlin, 1986). Gel permeation chromatography (9GPC) technique is used to separate the liqueid fraction when preparing fat, oils and plant extract for multi-residue pesticide analysis (Patterson, 1991). Samples containing high amount of fat or oil as well as coloring materials are often analyzed for pesticide residues, environmental contaminants or in toxicological studies. The cleanup of such samples can be carried out more efficiently, faster, simpler with gel permeation chromatography then applying the solvent partition.

\subsubsection{Filling of column}

A GPC column was washed and it was placed in the oven at $80^{\circ} \mathrm{C}$ for more than six hrs. About $6 \mathrm{~g}$ of Bio Beads SX-3 was taken in a long neck cylinder and added $50 \mathrm{ml}$ mobile phase (ethyl acetate and cyclohexane in 1:1 ratio). The Bio Beads was left over in the cylinder for 4-5 hours. After $5 \mathrm{hrs}$, the Biod Beads swelled up from $7 \mathrm{ml}$ up to $24 \mathrm{ml}$ in the cylinder. Then a fFilling Bottle was washed and placed in the oven at $100^{\circ} \mathrm{C}$ for $2 \mathrm{hrs}$ to avoid moisture. Bio Beads along with ethyl acetate and cyclohexane was placed in the Filling Bottle and the Bottle got attached

with nitrogen cylinder. Eventually, GPC column become filled with Bio Beads. The nitrogen gas was passed at a pressure of 2 bars from the Bottle. As the gas filled inside the bottle, it was started to move from Bottle into the column along with mobile phase. During the filling of column, the mobile phase was kept in continuous agitation so that all the Bio Beads moved from the Bottle into the GPC column. Care was taken during the transforming of Bio Beads along with mobile phase from Bottle into GPR column and there was no bubble formation in the column. The mobile phase passed from the column and was collected in the conical flask.

\subsubsection{Procedure for cleaning the oil from wheat samples}

Two small centrifuge tubes were taken. Pesticide was taken in on one tube and oil in the other. The flow rate of the mobile phase was maintained at 1.5 per minute. The reservoir of the GPC instrument was filled with mobile phase (ethyl acetate and cyclohexane in 1:1 ratio) up to $800 \mathrm{ml}$. About $0.5 \mathrm{ml}$ of the mobile phase was collected with Hamilton micro syringe. The syringe was emptied in those glass vials, which contained the evaporated sample. The vials were allowed to shock in a mini-shaker. Then the entire sample was collected in Hamilton micro syringe. The syringe was injected in GPC column at the inject sport. The sample, which came first from the column into the oil tube tend to change its color from yellow to transparent. This transparent sample was collected in the pesticide tube up to $11 \mathrm{ml}$. Then it was transferred into another vial. This oil free sample containing pesticide was poured under the nitrogen gas so that all the mobile phase got evaporated from the sample. The micro syringe was washed twice or thrice with acetone. Further $0.5 \mathrm{ml}$ of the mobile phase was collected in Hamilton micro syringe and added into another vial containing evaporated sample. The vial containing sample was allowed to shock in a small agitator or minishaker. Then the entire sample was collected in Hamilton micro syringe and injected into GPC column at the injector sport. The whole procedure was repeated using nitrogen gas in spite of pesticide. Same procedure was repeated for all samples. 
International Journal of Advances in Biology (IJAB) Vol 2. No .3, August 2015

\subsubsection{Thin Layer chromatography (TLC)}

The technique (HPTLC) is capable of producing fast, high-resolution separation and quantitative results with accuracy and precision with those obtained by gas chromatography (GC) and high performance liquid chromatography (HPTLC). The commission on pesticide chemistry has concluded that TLC is useful in multiresidue determination and qualification of the most important classes of pesticides (Batora et al., 1981).

\subsubsection{Hill reaction Method 2.2.3.1.1 Extraction of Chlorophyll Suspension}

Fresh wheat leaves (30 gram) were taken as test samples. These leaves were grounded in mortar and pestle until the mixture become completely homogenized. About $3 \mathrm{ml}$ glycerin and $15 \mathrm{ml}$ distilled water was added into the mixture. This chlorophyll suspension was transferred in fourlayer gauze Knapsack over a conical flask. The suspension was pressed with hand through thin cloth to get chlorophyll from leaves, flask was wrapped with aluminum foil and the extract was stored in refrigerator.

\subsection{Preparation of reagent solutions}

\section{Borax buffer solution}

Sodium borate solution was prepared by dissolving $9.5 \mathrm{~g}$ of sodium borate in $500 \mathrm{ml}$ distilled water. The $350 \mathrm{ml}$ solution was mixed with $150 \mathrm{ml} 0.1 \mathrm{~N} \mathrm{HCL}$ for making borax buffer solution and stored in refrigerator.

\section{DCPIP Solution}

200mg of 2.6-dichlorophenol-indophenol Na-salt was dissolved in $500 \mathrm{ml}$ borax buffer solution and stored in refrigerator.

\section{Detecting reagent}

Wheat $(10 \mathrm{ml})$ extract was mixed with $10 \mathrm{ml}$ of DCPIP solution and then added DCPIP solution drop-wise until the color of mixture became bluish green. This solution was enough for four plates of size $20 \times 20 \mathrm{~cm}$.

\section{Methodology}

Ready-made Silica gel 60 glass plates $20 \times 20 \mathrm{~cm}$ with $0.25 \mathrm{~mm}$ layer thickness was activated at $105 \mathrm{oC}$ for 30 minutes. The plates taken out from the oven were fixed in spotting rack and spotted the plates with samples extract with authentic standards according to pre-written scheme. These plates were developed in a saturated tank with ethyl acetate. After developing the plate, the extra solvent was evaporated in fume hood; the plate was sprayed with reagent solution (DCPIPchlorophyll) and put under light (60W bulb) for 5 minutes for the maximum visibility of sports. Measurements of sport area were performed immediately as spots disappear within 10 minutes. The color of the spot was bluish against the greenish background. Quantitative analysis was made 
comparing the average sport diameter of standard. Rf values of each compound was calculated and compared with the standard. The concentration of each compound was calculated by comparing the average spot are (horizontal and vertical area).

\subsubsection{High Performance Liquid Chromatography (HPLC)}

Today many sophisticated techniques are used to the determination of pesticide residue in vegetables, fruits, grains and water (Ritcher et al., 2001). Sample of wheat grains were analyzed by HPLC to compare the results f gas chromatography and thin layer chromatography following the methods of (Ohlin, 1986; Dekok and Hiemstra, 1992).

One $\mathrm{kg}$ of wheat was collected in 8 jars having capacity of $1 \frac{1 / 2}{\mathrm{Kg}}$. Deltamethrin and cypermethrin were sprayed in the concentration of 0.4 and $0.8 \%$ on wheat grains present in these jars. Pesticide solution @ 25ml/Kg was used for spraying the wheat grains in each jar.

\subsubsection{Preparation of mobile phase for HPLC}

Acetonotirile and water (80:20) mobile phase was used for detection of pyrethroid insecticides present in stored wheat grains. Mobile phase was filtered through $0.45 \mu \mathrm{m}$ filter paper with filtration assembly. After filtration, the mobile phase was sonicated for 15 minutes for complete eradication of air bubbles/dissolved oxygen from it.

\section{RESULTS AND DISCUSSION}

\section{Part A}

\subsection{Validation of Thin Layer Chromatographic (TLC) methods}

Validation is a pre-requisite of any reliable chromatographic analysis (Levison et al., 1997). Many chromatographic parameters have been proposed for inclusion in the validation process, such as linearity of the calibration curve, sensitivity and selectivity of solute detection, instrument precision, detection limit, quantification limit, recovery and ruggedness (Lee et al., 1995). Before analysis of the actual samples of wheat, TLS detection methods were validated and results are presented in (Table 1) and graphically represented in Figure 1. On the basis of validation of the TLC method, the $R_{f}$ and MDQ values of this method were used to assess the presence of weedicide residues in stored wheat.

Table 1: $\mathbf{R}_{\mathrm{f}}$ and MDQ values of standard of weedicides by Hill raction through TLC method.

\begin{tabular}{|l|c|c|}
\hline Weedicides & $\mathbf{R}_{\mathbf{f}}$ value & $\mathbf{M D Q}(\mathbf{n g})$ \\
\hline Atrazine & 0.63 & 0.5 \\
\hline Chlorbromuron & 0.62 & 2.2 \\
\hline Chlortoluron & 0.53 & 2 \\
\hline Isoprotron & 0.42 & 2.2 \\
\hline Linuron & 0.61 & 2 \\
\hline
\end{tabular}

$\mathrm{R}_{\mathrm{f}}$ values are mean of 5 replicates $\mathrm{MDQ}=$ maximum Detectable Quantity

\subsection{Behavior and Residual Analysis with TLC method}


Linear response was observed between quantity of pesticide and average spot diameter (horizontal and vertical diameter) in TLC detection method. Wheat samples were extracted by ethyl acetate and analyzed by TLC-Hill reaction method, which was very sensitive for the detection of herbicide residues. The extract was spotted on silica gel plate, which was developed in mobile phase (efhylacetate) and spot visibility was determined after spraying chlorophylldichlorophenol indophenols sodium reagent solution (10:5ml). $R_{f}$ value and average spot

diameter were measured and atrazine and isoproturon residues concentration in ppb were calculated comparing the standard regent spot diameter.

Table 2: Weedicide residues (ppb) in stored wheat in relation to different godowns

\begin{tabular}{|l|c|c|c|c|c|c|c|c|c|c|c|c|c|}
\hline \multirow{3}{*}{ Weedicide } & \multicolumn{10}{|c|}{ Weedicide residues in stored wheat(ppb)* } \\
\cline { 2 - 15 } & \multicolumn{10}{|c|}{ Sampling Sites (godowns) } \\
\cline { 2 - 14 } & $\mathbf{1}$ & $\mathbf{2}$ & $\mathbf{3}$ & $\mathbf{4}$ & $\mathbf{5}$ & $\mathbf{6}$ & $\mathbf{7}$ & $\mathbf{8}$ & $\mathbf{9}$ & $\mathbf{1 0}$ & $\mathbf{1 1}$ & $\mathbf{1 2}$ & $\mathbf{R}_{\mathbf{f}}$ \\
\hline Atrazine & 28.4 & 28.4 & N.D & 28.4 & 28.4 & N.D & 25.1 & 26.8 & 19 & N.D & 19 & 24 & 0.63 \\
& & & & & & & & & & & & & \\
\hline Isoprotron & N.D & 18.0 & N.D & N.D & N.D & 15.5 & 18 & N.D & N.D & 19.5 & 22 & 20.5 & 0.42 \\
& & & & & & & & & & & & & \\
\hline
\end{tabular}

*Values are the mean of 3 samples from different stored godowns

The quantity of atrazine and isoproturon in wheat samples were calculated comparing the average spot diameter of standard spot of the atrazine and isoproturon on the same plate under same condition. The results have been shown in Table 2.

\subsection{Weedicide residues (ppb) in stored wheat in relation to different godowns}

The data presented in (Table 2) revealed that the residues of atrazine in wheat grains at 3,6 and 10 sample sites (godowns) were not detected. The 3 sites (Godowns) 1, 2 and 4 contained the maximum amount of residues, which was $28.4 \mathrm{ng} / \mathrm{g}$, where as the remaining sites contained the atrazine, residues ranging between 19.5 to $26.8 \mathrm{ng} / \mathrm{g}$. It means that the range of atrazine residues was between 0 and $28.4 \mathrm{ng} / \mathrm{g}$ from all these sites in Faisalabad district. Thus, the values were below the maximum residue limit (MRL) which was $100 \mathrm{ngKg}^{-1}$ for atrazine. The data (Table 3) further revealed that highest residues of isoproturon $(24 \mathrm{ng} / \mathrm{g})$ were detected from sample site 12 . The residues of isoproturon in wheat grains collected from 1, 3, 4, 5, 8 and 9 sample sites (Godowns) were not detected, whereas the remaining sites contained the isoproturon residues $(15.5-22 \mathrm{ng} / \mathrm{g})$. It means that the range of isoproturon residues was between 0 and $24 \mathrm{ng} / \mathrm{g}$. The results revealed that isoproturon residues $\mathrm{w}(0-24 \mathrm{ng} / \mathrm{g})$ from all these sites in Faisalabad district. Thus, the values were far below the maximum residue limit (MRL) which was $2200 \mathrm{ngkg}^{-1}$ for isoproturon.

\subsection{Statistical Analysis}

\subsubsection{Weedicide residues in relation of different godowns}

The analysis of variance of data regarding variation between samples and between weedicides within wheat grains showed highly significant difference, i.e. $F(11,23)=250.42, p<0.00$. 
(DMRT at 5\%) indicated the highest quantity of weedicide residues (23.19 and $22.26 \mathrm{ppb}$ ) insample site 2 and 12 which were statistically similar to each other. These sample sites were also statistically similar to sample site 7 (21.54) but were significantly different from sample site 11 (20.48 ppb). The latter two were being statistically non-significant from each other. The sample sites 1 (14.19), 4 (14.21), 5 (13.42) and 8 (13.42) did not differ significantly from one another but were statistically different from the remaining sites. Sample sites 9 (9.47 ppb) and 10 (9.75) also did not differ statistically from each other. Sample site 6 showed statistically the lowest mean value of $7.75 \mathrm{ppb}$. No residues could however be dedicated in the sample site 3 .

Table 3: Mean values of weedicide residues in relation to different sample sites (godowns)

\begin{tabular}{|c|c|}
\hline Sample Site (godowns) & Weedicide residues \\
\hline 1 & $14.19 \mathrm{c}$ \\
\hline 2 & $23.19 \mathrm{a}$ \\
\hline 3 & $0.0000 \mathrm{f}$ \\
\hline 4 & $14.21 \mathrm{c}$ \\
\hline 5 & $13.42 \mathrm{c}$ \\
\hline 6 & $7.750 \mathrm{e}$ \\
\hline 7 & $21.54 \mathrm{ab}$ \\
\hline 8 & $13.42 \mathrm{c}$ \\
\hline 9 & $9.475 \mathrm{~d}$ \\
\hline 10 & $9.750 \mathrm{~d}$ \\
\hline 11 & $20.48 \mathrm{~b}$ \\
\hline 12 & $22.26 \mathrm{a}$ \\
\hline
\end{tabular}

Means sharing same letters are not significantly different by DMR test at $\mathrm{p}<0.05$.

\subsubsection{Weedicide residues in relation to interaction between Godowns $\mathbf{x}$ Weedicides}

The results given in (Table 5) revealed that nine sample sites (godowns) viz., 1, 5, 6, 7, 9, 12, 15, 17 and 20 did not show presence of weedicide residues. Sample site (godowns) 2, 4, 8, 10 and 16 showed the highest quantity of weedicide residues ranging between 28.39 and $26.48 \mathrm{ppb}$ which did not differ significantly from one another but were statistically different from the remaining sample sites excepting sample site $14(25.09 \mathrm{ppb})$ which was statistically similar to sample site 10 (26.84) and 16 (26.84) on the higher side and sample site 23 (24.00 ppb) on the lower side. 
International Journal of Advances in Biology (IJAB) Vol 2. No .3, August 2015

Sample sites 23 (24.00) and 21 (22.00) were statistically at par with each other, the latter also being statistically similar to sample site 19 (19.5-0). Sample site 22 (18.95), 18 (18.95), 13 (18.00), 3 (18.00) and $11(15.50 \mathrm{ppb})$ were statistically at par with one another.Uddin et al. (2011) used capillary gas chromatography technique to test the residues of organochlorine, organophosphorus, pyrethroids and herbicides in fortified rice samples. Recovery was checked at 0.1 and $0.5 \mu \mathrm{g} / \mathrm{g}$. It was found that average recovery was $74 \%-111 \%$ and $\% \mathrm{RSD}$ in the range of $2.41-12.42$.

Table 4: Mean Value of Weedicide residues in relation to interaction between weedicide applied and sample sites (godowns)

\begin{tabular}{|c|c|}
\hline Weedicide $\mathrm{x}$ godowns & Weedicide residues \\
\hline 1 & $0.0000 \mathrm{~h}$ \\
\hline 2 & $28.39 \mathrm{a}$ \\
\hline 3 & $18.00 \mathrm{fg}$ \\
\hline 4 & $28.39 \mathrm{a}$ \\
\hline 5 & $0.0000 \mathrm{~h}$ \\
\hline 6 & $0.0000 \mathrm{~h}$ \\
\hline 7 & $0.0000 \mathrm{~h}$ \\
\hline 8 & $28.42 \mathrm{a}$ \\
\hline 9 & $0.0000 \mathrm{~h}$ \\
\hline 10 & $26.84 \mathrm{ab}$ \\
\hline 11 & $15.50 \mathrm{~g}$ \\
\hline 12 & $0.0000 \mathrm{~h}$ \\
\hline 13 & $18.00 \mathrm{fg}$ \\
\hline 14 & $25.09 \mathrm{bc}$ \\
\hline 15 & $0.0000 \mathrm{~h}$ \\
\hline 16 & $26.84 \mathrm{ab}$ \\
\hline 17 & $0.0000 \mathrm{~h}$ \\
\hline 18 & $18.95 \mathrm{f}$ \\
\hline 19 & $19.50 \mathrm{ef}$ \\
\hline 20 & $0.0000 \mathrm{~h}$ \\
\hline 21 & $22.00 \mathrm{de}$ \\
\hline 22 & $18.95 \mathrm{f}$ \\
\hline 23 & $24.00 \mathrm{~cd}$ \\
\hline 24 & $20.53 \mathrm{ef}$ \\
\hline
\end{tabular}

Means sharing same letters are not significantly different by DMR test at $\mathrm{p}<0.05$.

\section{Part B}

\subsection{Cypermethrin and deltamethrin residues determination in stored grains}

This is a usual practice to apply parathyroid insecticides for the control of insect pests infesting wheat grain during storage. Residues of cypermethrin and deltamethrin were determined by applying these insecticides at 0.4 and $0.8 \%$ concentrations at different intervals i.e. 1, 7, 15 and 30 day after spraying. For this purpose HPLC method was used. In the $1^{\text {st }}$ step the method applied was validated and used for the determination of residues present in wheat grains using reverse 
International Journal of Advances in Biology (IJAB) Vol 2. No .3, August 2015

phase system with UV detector.

\subsubsection{HPLC Standardization}

HPLC system was standardized to check the performance of column and detector, suitability of mobile phase on resolution and linearity and ruggedness of the instrument. To evaluate the above parameters, pesticide standard solutions were run. Data showed that the instrument, column, detector and conditions were suitable for the analysis of parathyroid residues in the wheat grains. Methanol/water and acetonotiril/water were used as mobile phase for validation of the instrument 
as well as for the analysis of pesticide residues in the wheat grains. Chromatograms of standards are given in Figure 1

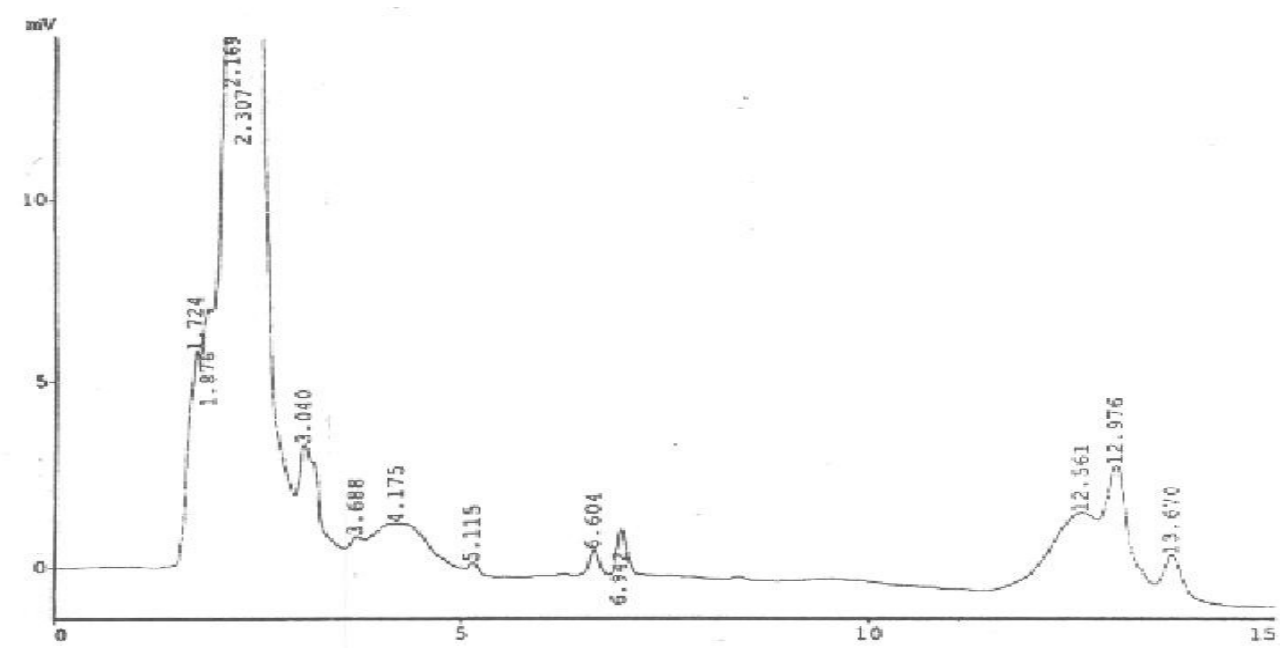

Figure 1 Standard of Cypermethrin and Deltamethrin

\subsection{HPLC Analysis}

The cypermethrin and deltamethrin residues in wheat grains were determined by reverse-high performance liquid chromatography at fixed wavelength.

\subsubsection{Residues of cypermethrin (10 EC) and deltamethrin (50 EC) applied @ 0.4 and $0.8 \%$ in stored wheat at different intervals after spraying}

The cypermethrin residues (Table 5) were observed at 1 hour after spraying were $157.27 \mathrm{ppb}$ which continuously degraded to $102.27,37.83$ and $34.6 \mathrm{ppb}$ on 7,15 and 30 days, respectively, after the spraying of cypermethrin. Similarly, the maximum amount od deltamethrin residues were $101.04 \mathrm{ppb}$ at thereafter 1 hour after spraying which degraded to $69.23,31.95$ and 25.33 $\mathrm{PPb}$ by 7,15 and 30 day of spray.

The cypermethrin residues (Table 5) were observed 1 hour after spraying were $266.66 \mathrm{ppb}$, which continuously degraded to $133.45,104.16$ and 89.3 ppb by 7,15 and 30 day, respectively, afer the spraying of cypermethrin on the stored wheat. Similarly, the maximum amount of deltamethrin residues were $162.47 \mathrm{ppb}$ at 1 hour after spraying, which degraded to $111.64,80.01$ and 66.13 ppb at 7, 15 and 30 day of spray.

Riazuddin et al. (2011a) tested domestic stored wheat and imported wheat grains for residual analysis of organochlorine, organophosphorus and pyrethroids. It was found that about $22.5 \%$ of test samples in imported wheat were contaminated with organophosphorus (chlorpyrifos 0.073- 
$0.230 \mu \mathrm{g} / \mathrm{g}$, malathion $0.0419-0.1003 \mu \mathrm{g} / \mathrm{g}$ ) and pyrethroids (cypermethrin $0.1404-0.2005 \mu \mathrm{g} / \mathrm{g}$, permethrin $0.0140-0.0480 \mu \mathrm{g} / \mathrm{g}$ ). In domestic wheat about $6.7 \%$ of test samples were found

contaminated by pyrethroids (deltamethrin $0.0650-1.2903 \mu \mathrm{g} / \mathrm{g}$ ). The average recovery range of fortified wheat samples was about (73.77\%-100.17\%) with RSD (2.21-9.27).

Table 5: Residues of cypermethrin (10 EC) and deltamethrin (50 EC) applied @ 0.4 and $0.8 \%$ in stored wheat at different intervals after spraying

\begin{tabular}{|l|c|c|c|c|}
\hline \multirow{3}{*}{ Grain protectants } & \multicolumn{4}{|c|}{ Sampling Interval (days) } \\
\cline { 2 - 5 } & \multicolumn{4}{|c|}{ Residues @ 0.4\% (ppb)* } \\
\cline { 2 - 5 } & $\mathbf{1}(\mathbf{h r})$ & $\mathbf{7}$ & $\mathbf{1 5}$ & $\mathbf{3 0}$ \\
\hline \multirow{2}{*}{ Cypermethrin } & 157.27 & 102.27 & 37.83 & 34.60 \\
\hline \multirow{2}{*}{ Deltamethrin } & 101.04 & 69.23 & 31.95 & 25.33 \\
\hline & & Residues @ 0.8\% (ppb)* & \\
\hline \multirow{2}{*}{ Cypermethrin } & 266.66 & 133.45 & 104.16 & 89.30 \\
\hline Deltamethrin & 162.47 & 111.64 & 80.01 & 66.13 \\
\hline
\end{tabular}

*Values are mean of three samples

\subsection{Statistical Analysis}

The analysis of data (Table 6) revealed that the results with regard to interval after spraying, residues of grain protectants and the two concentration applied were statistically significant. The interactions viz., interval after spraying $\mathrm{x}$ the two concentrations applied, residues of grain protectants $\mathrm{x}$ the two concentration applied were also statistically significant with mean values of $0.4049,0.2863,0.5727,0.2863,0.5727,0.4049$ and 8090, respectively. 
Table 6: Analysis of Variance with CRD

\begin{tabular}{|c|c|c|c|c|c|c|}
\hline K Value & S.O.V. & df & SS & MS & F Value & Probability \\
\hline 2 & $\begin{array}{l}\text { Interval after } \\
\text { spraying }(\mathrm{A})\end{array}$ & 3 & 103606.3 & 34535.45 & 17550.645 & $0.000 * *$ \\
\hline 4 & $\begin{array}{l}\text { Residues of } \\
\text { grain } \\
\text { protectants } \\
\text { (B) }\end{array}$ & 1 & 14463.65 & 14463.65 & 7350.3164 & $0.000 * *$ \\
\hline 6 & $(\mathrm{AB})$ & 3 & 8559.283 & 2853.094 & 1449.9200 & $0.000 * *$ \\
\hline 8 & $\begin{array}{l}\text { Factor C } \\
\text { (two conc. } \\
\text { applied) }\end{array}$ & 1 & 38697.84 & 38697.84 & 19665.936 & $0.000 * *$ \\
\hline 10 & $(\mathrm{AC})$ & 3 & 3902.371 & 1300.790 & 661.0513 & $0.000 * *$ \\
\hline 12 & $(\mathrm{BC})$ & 1 & 890.102 & 890.102 & 452.3428 & $0.000 * *$ \\
\hline 14 & $(\mathrm{ABC})$ & 3 & 1324.856 & 441.619 & 224.4271 & $0.000 * *$ \\
\hline-15 & Error & 32 & 62.968 & 1.968 & & \\
\hline & Total & 47 & 171507.4 & & & \\
\hline
\end{tabular}

**Highly significant

\subsubsection{Residues of grain protectants at different interval after spraying}

By using DMRT, overall mean values of cypermethrin and deltamethrin residues were found $171.9,104.1,63.49$ and $53.84 \mathrm{ng} / \mathrm{g}$ after 1 hour of spraying 7, 15 and 30 day of treatment which differed statistically from each another (Table 7).

Table 7: Residues of grain protectants at different interval after spraying

Number of observations utilized to calculate a mean $=12$

\begin{tabular}{|c|c|}
\hline Interval after spraying & Residues of grain protectants \\
\hline 1 & $171.9 \mathrm{a}$ \\
\hline
\end{tabular}




\begin{tabular}{|c|c|}
\hline 2 & $104.1 \mathrm{~b}$ \\
\hline 3 & $63.49 \mathrm{c}$ \\
\hline 4 & $53.84 \mathrm{~d}$ \\
\hline
\end{tabular}

Means followed by same letters do not differ significantly

\subsubsection{Residues of grain protectants in relation to interaction (Interval after spraying $x$ Residues of grain Protectants)}

The residues of grain protectants and their interaction with intervals after spraying (Table 8) predicted that these were statistically different from one another. The maximum residues of cypermethrin and deltamethrin insecticides were observed in the first interaction after the treatment with the mean value of $212 \mathrm{ppb}$ for cypermethrin and deltamethrin followed by 2, 3, 4, 5, 7, 6 and 8 with mean values of 212, 131.8, 117.9, 90.43, 71, 61.95, 55.98 and $47.73 \mathrm{ppb}$, respectively which were statistically different from one another.

Table 8:Residues of grain protectants in relation to interaction (Interval after spraying x Residues of grain protectants)

Number of observations utilized to calculate a mean $=6$

\begin{tabular}{|c|c|}
\hline $\begin{array}{c}\text { Interval after spraying x Residues } \\
\text { of grain protectants }\end{array}$ & $\begin{array}{c}\text { Residues of grain } \\
\text { protectants }\end{array}$ \\
\hline 1 & $212 \mathrm{a}$ \\
\hline 2 & $131.8 \mathrm{~b}$ \\
\hline 3 & $117.9 \mathrm{c}$ \\
\hline 4 & $90.43 \mathrm{~d}$ \\
\hline 5 & $71.00 \mathrm{e}$ \\
\hline 6 & $55.98 \mathrm{~g}$ \\
\hline 7 & $61.95 \mathrm{f}$ \\
\hline 8 & $45.73 \mathrm{~h}$ \\
\hline
\end{tabular}

Means followed by same letters do not differ significantly 


\subsubsection{Residues of grain protectants in relation to interaction (Interval after spraying $\mathrm{x}$ Two concentrations applied)}

The interaction between the intervals $\mathrm{x}$ two concentrations applied (Table 9) were statistically different from one another. The maximum residues of cypermethrin and deltamethrin were observed in the Table 2 interaction after the treatment with the mean value of $214.6 \mathrm{Ppb}$ followed by $1^{\text {st }}, 4^{\text {th }}, 6^{\text {th }}, 3^{\text {rd }}, 8^{\text {th }}, 5^{\text {th }}$ and $7^{\text {th }}$ with mean values of $129.2,122.5,92.08,85.75,77.72,34.89$ and $29.97 \mathrm{ppb}$, respectively which were statistically different from one another.

Table 9: Residues of grain protectants in relation to interaction (Interval after spraying $\mathrm{x}$ Two concentration applied)

Number of observations utilized to calculate a mean $=6$

\begin{tabular}{|c|c|}
\hline $\begin{array}{c}\text { Interval after spraying } \mathbf{x} \text { Two } \\
\text { concentrations applied }\end{array}$ & $\begin{array}{c}\text { Residuesofgrain } \\
\text { protectants }\end{array}$ \\
\hline 1 & $129.2 \mathrm{~b}$ \\
\hline 2 & $214.6 \mathrm{a}$ \\
\hline 3 & $85.75 \mathrm{e}$ \\
\hline 4 & $122.5 \mathrm{c}$ \\
\hline 5 & $34.89 \mathrm{~g}$ \\
\hline 6 & $92.08 \mathrm{~d}$ \\
\hline 7 & $29.97 \mathrm{~h}$ \\
\hline 8 & $77.72 \mathrm{f}$ \\
\hline
\end{tabular}

Means followed by same letters do not differ significantly

\subsubsection{Residues of grain protectants in relation to interaction (Residues of grain protectants x Two concentrations applied)}

The overall mean values for interaction (Residues of grain protectants $\mathrm{x}$ Two concentrations applied) showed in (Table 10) that the results were statistically significant. The overall mean values indicated that the cypermethrin and deltamethrin insecticides and their residues with mean values of 148.4, 105.1, 82.99 and 56.89 were statistically different from one another.

Table 10: Residues of grain protectants in relation to interaction (Interval after spraying $\mathrm{x}$ Residues of grain protectant $\mathrm{x}$ Two concentration applied)

Number of observations utilized to calculate a mean $=12$

\begin{tabular}{|c|c|}
\hline $\begin{array}{l}\text { Residues of grain protectants } \mathbf{x} \\
\text { Two concentrations applied }\end{array}$ & Residues of grain protectants \\
\hline 1 & $82.99 \mathrm{c}$ \\
\hline 2 & $148.4 \mathrm{a}$ \\
\hline 3 & $56.89 \mathrm{~d}$ \\
\hline 4 & $105.1 \mathrm{~b}$ \\
\hline
\end{tabular}


Means followed by same letters do not differ significantly

\subsubsection{Residues of grain protectants in relation to interaction (Interval after spraying $x$ Residues of grain protectants $x$ Two concentrations applied)}

The overall mean values for interaction (Interval after spraying $\mathrm{x}$ Residues of grain protectant $\mathrm{x}$ Two concentrations applied) shown in (Table 11) that the results were statistically significant. The overall mean values indicated that the residues of grain protectants were 266.7, 162.5, 157.3, $133.4,111.6,104.2,89.30,80.01,69.23,66.13,37.83,34.60,31.95$ and 25.33 ppb statistically different from one another.

Kolberg et al. (2011) reported that validation of gas chromatography coupled to mass spectrometry (GC-MS (NCI-SIM)) for determination of 24 pesticides in wheat, white flour and bran can exactly calculate the linearity, limit of detention, limit of quantification, matrix effect

and recovery percentage. It was found that the linear range in calibration curve was (1.0 to $100 \mu \mathrm{g}$ $\left.\mathrm{L}^{-1}\right)$ for wheat and $\left(2.0\right.$ to $\left.200 \mu \mathrm{g} \mathrm{L}^{-1}\right)$ for flour and bran. The determination coefficient was $\left(\mathrm{r}^{2}\right) \geq$ 0.99 for all pesticides. The recovery values were $70-120 \%$ with RSD $<20 \%$ for majority of tested pesticides.

Table 11: Residues of grain protectants and relation to interaction (Interval after spraying $\mathrm{x}$ Residues of grain protectants $\mathrm{x}$ Two concentration applied)

Number of observations utilized to calculated a mean $=3$

\begin{tabular}{|c|c|}
\hline $\begin{array}{l}\text { Interval after spraying } \\
\text { Residues of grain protectants } \mathbf{x} \\
\text { Two concentrations applied }\end{array}$ & Residues of grain protectants \\
\hline 1 & $157.3 \mathrm{c}$ \\
\hline 2 & $266.7 \mathrm{a}$ \\
\hline 3 & $101.0 \mathrm{~g}$ \\
\hline 4 & $162.5 \mathrm{~b}$ \\
\hline 5 & $102.3 \mathrm{fg}$ \\
\hline 6 & $133.4 \mathrm{~d}$ \\
\hline 7 & $69.23 \mathrm{j}$ \\
\hline 8 & $111.6 \mathrm{e}$ \\
\hline 9 & $37.83 \mathrm{l}$ \\
\hline 10 & $104.2 \mathrm{f}$ \\
\hline 11 & $31.95 \mathrm{n}$ \\
\hline 12 & $80.01 \mathrm{i}$ \\
\hline 13 & $34.60 \mathrm{n}$ \\
\hline 14 & $89.30 \mathrm{~h}$ \\
\hline 15 & $25.33 \mathrm{o}$ \\
\hline 16 & $66.13 \mathrm{k}$ \\
\hline &
\end{tabular}

Means followed by same letters do not differ significantly 


\section{CONCLUSION}

Since 1960s, grain protectants are being used for pest control in storage (Arthur, 1996). Grain protectants used must be safer to mammals. It must have low mammalian toxicity, easier in application. It must be broad spectrum towards stored grain insect pests. It must have low price that the economic viability should not be affected (Korunic et al. 2010). Pyrethroids are nonpersistent because their biomagnification in the food chain is negligiable. They act as negative temperature coefficient of toxicity (Polat et al. 2002). The grain protectants used in this experiment were continuously degraded with the passage of time. It was found that after the 30 days the amount of residues of the grain protectants was found to be very small. It was concluded that the use of the grain protectants in the powder form in combination with other botanicals on stored wheat grains is feasible to reduce the use of phosphine against the insect pest in stored grains.

\section{REFERENCES}

[1] Aldana-Madrid ML, Valdez-Hurtado S, Vargas-Valdez ND, Salazar-Lopez NJ, Silveria-Gramont MI, Loarca-Pina FG, Rodriguez-Olibarria G, Wong-Corral GJ, Borboa-Flores J and Burgos-Herzandez A. 2008. Insecticide residues in stored grain in Sonora, Mexico: quantification and toxicity testing. Bull Environ Contam Toxicol. 80(2):93-96.

[2] Alletto L, Coquet Y, Benoit P and Bergheaud V. 2006. Effects of temperature and water content on degradation of isoproturon in three soil profiles. Chemosphere. 64(7):1053-1061.

[3] Anderson A and Ohlin B. 1986. A capilillary gas chromatographic multiresidue method for determination of pesticide residues in fruits and vegetables. Var Foda Sup. 86(2): 79-109.

[4] Anwar A, Ahmad I and Tahir S. 2011. Determination of pesticide residues in fruits of Nawabshah District, Sindh, Pakistan. Pak J Bot. 43(2): 1133-1139.

[5] Arthur FH. 1996. Grain Protectants: Current Status and Prospects for the Future. J stored Prod Res. 32(4): 293-302.

[6] Baghestani MA, Zand E, Rahimian-Mashhadi H, and Soufizadeh S. 2005. Morphological and physiological characteristics which enhance competitiveness of winter wheat (Triticum aestivum L.) against Goldbachia laevigata. Iranian J Weed Sci. 1:111-126.

[7] Batora V, Vitrocic SLJ, Their HP and Klisenko MA. 1981. Development and evaluation of simplified approaches to residue analysis. Pure Appl chem. 53(5):1039-1049.

[8] Cairns TM, Luke A, Chiu KS, Navarro KS and Siegmund E. 1993. Multiresidue pesticide analysis by ion-trap mass spectrometry. Rapid Commun Mass Sp. 7(1): 971-998.

[9] Cesnik HB, Gregorcic A, Bolta SV and Kmecl V. 2007. Pesticide residues in agricultural produce of Slovene origin in the period from 2001 to 2005 . Acta alimentaria. 36(2):269-282.

[10] Chitanat CN, Chaibu PP and Traichaiyaporn S. 2008. The use of acetylcholinesterase inhibition in river snails (Sinotaia ingallsiana) to determine the pesticide contamination in the Upper Ping River. Int J Agri Biol. 10(6): 658-660. 
[11] Daglish GJ. 1998. Efficacy of six grain protectants applied alone or on combination against three species of Coleoptera. J stored Prod Res. 34(4):263-268.

[12] Das BK and Mukherjee SC. 2003. Toxicity of cypermethrin in Labeo rohita fingerlings: biochemical, enzymatic and haematological consequences. Comp Biochem Phys C. 134(1):109-121.

[13] Dekok, A. and M. Hiemstra. 1992. Optimization, automation and validation of the solid-phase extraction cleanup and on-line liquid chromatographic determination of $\mathrm{N}$-methylcarbamate pesticides in fruits and vegetables. J.O.A.A.C. 75(6):1063-1072.

[14] Elbetieha A, Da'as SI, Khamas W and Darmani H. 2001. Evaluation of the toxic potentials of cypermethrin pesticide on some reproductive and fertility parameters in the male rats. Arch Environ Con Tox. 41(4):522-528.

[15] European Commission. 2004. Commission Decision of 10 March 2004 concerning the non-inclusion of atrazine in Annex I to Council Directive 91/414/EEC and the withdrawal of authorisations for plant protection products containing this active substance, 2004/248/EC. OJEU. L.78:53-55.

[16] Freeman LEB, Rusiecki JA, Hoppin JA, Lubin JH, Koutros S, Andreotti G, Zahm SH, Hines CJ, Coble JB, Barone-Adesi F, Sloan J, Sandler DP, Blair A and Alavanja MCR. 2011. Atrazine and Cancer Incidence Among Pesticide Applicators in the Agricultural Health Study (1994-2007). Environ Health Persp. 119(9): 1253-1259.

[17] Friedman A. 2002. Atrazine inhibition of testosterone produc $\neg$ tion in rat males following peripubertal exposure. Reprod Toxicol. 16(3):275-279.

[18] Gowlan BT, Moffat CF, Stagg RM, Houlihan DF and Davies IM. 2002. Cypermethrin induces glutathione S-transferase activity in the shore crab, Carcinus maenas. Mar Environ Res. 54(2):169177.

[19] Guo-Fang P, Yong-Ming L, Chun-Lin F, Jin-Jie Z, Yan-Zhong C, Xue-Min L, Zeng-Yin L, Yan-Ping $\mathrm{W}$ and Tong-Tong G. 2006. Simultaneous determination of 405 pesticide residues in grain by accelerated solvent extraction then gas chromatography-mass spectrometry or liquid chromatographytandem mass spectrometry. Anal Bioanal Chem. 384:1366-1408.

[20] Hayes TB, Khoury V, Narayan A, Nazir M, Park A, Brown T, Adame L, Chan E, Buchholz D, Stueve $\mathrm{T}$ and Gallipeauet S. 2010. Atrazine induces complete feminization and chemical castration in male African clawed frogs (Xenopus laevis). Proc Natl Acad Sci USA. 107(10):4612-4617.

[21] Indexmundi, 2013. United States Department of Agriculture. [cited: 27 Nov, 2013]. Available from:http://www.indexmundi.com/agriculture/?country=pk\&commodity=wheat\&graph=production.

[22] Khan IAT, Parveen Z, Riazuddin and Ahmed M. 2007. Multi-residue determination of organophosphorus pesticides and synethetic pyrethroids in wheat. Int J Agric Biol. 9(6): 905-908.

[23] Kolberg, DI, Prestes OD, Adaime MB and Zanella R. 2011. Development of a fast multiresidue method for the determination of pesticides in dry samples (wheat grains, flour and bran) using QuEChERS based method and GC-MS. Food Chemistry. 125(4):1436-1442.

[24] Korunic Z, Kalinovic I, Liska A and Hamel D. 2010. Long term effectiveness of the mixture of diatomaceous earth and deltamethrin on wheat. 10th International Working Conference on Stored Product Protection. Julius-Kühn -Archiv. 425: 858-862.

[25] Lee PW. 1985. Fate of fenvelrate in the soil environment. J Agric Food Chem. 33(5):993-998. 
[26] Levison PR, Mumford C, Streater M, Brandt-Nielsen A, Pathirana ND and Badger, SE. 1997. Performance comparison of low-pressure ion-exchange chromatography media for protein separation. J Chromatogr A. 760(1):151-158.

[27] Mamy L, Vrignaud P, Cheviron N, Perreau F, Belkacem M, Brault A, Breuil S, Delarue G, Pe'traud J, Touton I, Mougin C and Chaplain V. 2011. No evidence for effect of soil compaction on the degradation and impact of isoproturon. Environ Chem Lett. 9(1):145-150.

[28] Mast M, Foreman W and Skaates S. 2007. Current-use pesticides and organochlorine compounds in precipitation and lake sediᄀment from two high -elevation national parks in the Western United States. Arch Environ Contam Toxicol. 52(3):294-305.

[29] Matsushita S. 2006. Effects of in ovo exposure to imazalil and atrazine on sexual differentiation in chick gonads. Poult Sci. 85:1641-1647.

[30] Mohler CL. 2001. Enhancing the competitive ability of crops. In: Ecological Management of Agricultural Weeds, (Eds.: Liebman M, Mohler CL and Staver CP.). Cambridge, U.K. Cambridge University Press. 269-374pp.

[31] Najafi $\mathrm{H}$ and Tollenaar T. 2005. Response of corn at leaf stages to shading by redroot pigweed (Amaranthus retroflexus L.). Iranian J Weed Sci 1:127-140.

[32] Najafi B and Ghadiri H. 2012. Weed Control and Grain Yield Response to Nitrogen Management and Herbicides. J Biol Environ Sci. 6(16): 39-47.

[33] O'Donovan JT, Harker KN, Clayton GW, Robinson D, Blackshaw RE, and Hall L. 2001. Implementing integrated weed management in barley (Hordeum vulgare). In: Integrated Weed Management: Explore the Potential, (Eds.: R.E. Blackshaw and L.M. Hall). Sainte-Anne-de-Bellevue, Quebec: Expert Committee on Weeds.75-89pp.

[34] Ohlin B. 1986. A high performance liquid chromatography multiresidue method for determination of pesticides in fruits and vegetables. Var Foda Suppl. 2/86:111-124.

[35] Pang GF, Cao YZ, Fan CL and Liu YM. 2009. Analysis method study on 839 pesticide and chemical contaminant multiresidues in animal muscles by gel permeation chromatography cleanup, GC/MS and LC/MS/MS. JAOAC Int. 92:933-940

[36] Patterson JR. 1991. Reducing solvent consumption in automated gel permeation chromatographic clean up for pesticide residues analysis. A modification GPC autoprep 1002. J. AOAC. 74(6):10161018 .

[37] Phillips TW, Throne JE. 2010. Biorational approaches to managing stored-product insects. Annu Rev Entomol. 55:375-397.

[38] Polat H, Erkoc FU, Viran R and Kocak O. 2002. Investigation of acute toxicity of beta-cypermethrin on guppies Poecilia reticulate. Chemosphere. 49(1):39-44.

[39] Rao VS. 2000. Principles of Weed Science. 2nd Ed, Science Publishers, Inc., New Hampshire. 555p.

[40] Rehman R, Shah KN, Masood S, Arshad M and Ghafoor A. 2013. Genetic divergence among Pakistani bread wheat varieties and advanced lines for randomly amplified polymorphic DNA (RAPD) markers. Pak J Bot. 45(S1):327-332. 
[41] Ritcher BE, Hoefler F and Linkerhaegner M. 2001. Determining organophosphorus pesticides in foods using accelerated solvent extraction with large sample sizes. LC-GC. (19):408-412.

[42] Riazuddin, Khan MF, Iqbal S, Abbas M. 2011a. Determination of Multi-residue Insecticides of Organochlorine, Organophosphorus, and Pyrethroids in Wheat. Bull Environ Contam Toxicol. 87(3):303-306.

[43] Riazuddin ZP, Iqbal S, Khuhro MI, Bhutto MA and Ahmed M. 2011b. Monitoring of multiple pesticide residues in some fruits in Karachi, Pakistan. Pak J Bot. 43(4): 1915-1918.

[44] Solati J, Hajikhani R and Zaeim RT. 2010. Effects of cypermethrin on sexual behaviour and plasma concentrations of pituitary-gonadal hormones. Int J Fertil Steril. 4(1):23-28.

[45] Sørensen SR, Bending GD, Jacobsen CS, Walker A and Aamand J. 2003. Microbial degradation of isoproturon and related phenyl urea herbicides in and below agricultural fields. FEMS Microbiol Ecol. 45(1):1-11.

[46] Steinberg CEW, Lorenz R and Spieser OH. 1995. Effects of atrazine on swimming behaviour of zebra fish, Brachydanio rario. Water Res. 29(3):981-985.

[47] Thurman E and Cromwell A. 2000. Atmospheric transport, deposintion, and fate of triazine herbicides and their metabolites in pristine areas at Isle Royale National Park. Environ Sci Technol. 34(15):3079-3085.

[48] Uddin R, Iqbal S, Khan MF, Parveen Z, Ahmed M and Abbas M. 2011. Determination of Pesticide Residues in Rice Grain by Solvent Extraction, Column Cleanup, and Gas Chromatography-Electron Capture Detection. Bull Environ Contam Toxicol. 86(1):83-89.

[49] Wolansky MJ and Harrill JA. 2008. Neurobehavioral toxicology of pyrethroid insecticides in adult animals: A critical review. Neurotoxicol Teratol. 30(2):55-78.

[50] Zand E, Baghestani MA, Soufizadeh S, PourAzar R, Veysi M, Bagherani N, Barjasteh A, Khayami MM and Nezamabadi N. 2007. Broadleaved weed control in winter wheat (Triticum aestivum L.) with post-emergence herbicides in Iran. Crop Protection. 26(5): 746-752. 